\title{
Çelik Yapıların Kaynaklı Birleşimlerinin Metasezgisel Yöntemlerle Optimum Tasarımı
}

\section{Optimum Design of Welded Connections of Steel Structures Using Metaheuristic Methods}

\author{
Soner Sezer ${ }^{* * 1}$, Murat Hiçyılmaz ${ }^{2 \oplus}$ \\ ${ }^{1}$ Afyon Kocatepe Üniversitesi, Fen Bilimleri Enstitüsü, İnşaat Mühendisliği Anabilim Dalı, Afyonkarahisar, TÜRKIYE \\ ${ }^{2}$ Afyon Kocatepe Üniversitesi, Mühendislik Fakültesi, İnşaat Mühendisliği Bölümü, Afyonkarahisar, TÜRKIYE \\ Sorumlu Yazar / Corresponding Author*: sonersezer@outlook.com.tr \\ Geliş Tarihi / Received: 01.05.2021 \\ Araştırma Makalesi/Research Article \\ Kabul Tarihi / Accepted: 30.09 .2021 \\ DOI:10.21205/deufmd.2022247025 \\ Atıfsekli/How to cite: SEZER, S., HIÇYILMAZ, M.(2022).Çelik Yapıların Kaynaklı Birleşimlerinin Metasezgisel Yöntemlerle Optimum Tasarımı. \\ DEUFMD, 24(70), 277-290
}

$\ddot{0} \mathbf{z}$

Bu çalıșmada; Jaya, TLBO ve Sinüs-Kosinüs algoritmaları kullanılarak çelik yapıların kaynaklı birleşimlerinin optimum tasarımının yapılması, kullanılan metasezgisel algoritmaların bu çalışmadaki sayısal modeller ekseninde birbirlerine göre avantaj ve dezavantajlarının belirlenmesi ve bu çalışmada ortaya konan Adil Ceza Yöntemi'nin kısıtlı optimizasyon problemlerinin çözümü için kullanılabilirliğinin araștırılması hedeflenmiştir. İlgili hedefler doğrultusunda köșe kaynaklı bir bağlantıdan, Çelik Yapıların Tasarım, Hesap ve Yapımına Dair Esaslar - 2018'de belirtilen gereklilikleri sağlayan üç adet sayısal model oluşturulmuştur. Yönetmelikte tanımlanan Yük ve Dayanım Katsayıları ile Tasarım (YDKT) ve Güvenlik Katsayıları ile Tasarım (GKT) yöntemleri için üç farklı popülasyon büyüklügü kullanılarak 54 farklı analiz gerçekleștirilmiştir. Yapılan incelemeler neticesinde, ele alınan algoritmaların çelik yapıların kaynaklı birleşimlerin optimizasyonu için uygun olduğu anlaşılmış olup algoritmaların birbirlerine göre avantaj ve dezavantajları ortaya konulmuştur. Bununla beraber, bu çalıșmada sunulan Adil Ceza Yöntemi'nin kısıtlı optimizasyon problemlerinin çözümünde kullanılabilir olduğu görülmüştür.

Anahtar Kelimeler: Çelik Yapılar, Kaynaklı Birleşimler, Optimizasyon, Metasezgisel Algoritmalar

Abstract

In this study, it is aimed to make optimum design of welded joints of steel structures using Jaya, TLBO and Sine-Cosine algorithms, to determine the advantages and disadvantages of the metaheuristic algorithms used in this study in terms of numerical models and to investigate the usability of the "Fair Penalty Method" presented in this study for solving constrained optimization problems. For these goals, three numerical models are created from the fillet welded connection in accordance with the CYTHYDE-2018 regulation. 54 different analyzes are carried out using three different population sizes for the Load and Resistance Factor Design (LRFD) and Allowable Strength Design (ASD) methods defined in the regulation. As a result of the investigations, it is understood that the algorithms considered are suitable for the optimization of welded joints of steel structures, and the advantages and disadvantages of the algorithms compared to each other are revealed. In addition, it is observed that the Fair Penalty Method presented in this study is useable in solving constrained optimization problems.

Keywords: Steel Structures, Welded Connections, Optimization, Metaheuristic Algorithms 


\section{Giriş}

Artan dünya nüfusu ve buna bağlı olarak azalan doğal kaynaklar neticesinde optimizasyon kavramı, günümüzde popüler bir çalışma konusu haline gelmiștir. Optimizasyon, yüzyıllar boyunca çeşitli yöntemlerle yapılagelse de günümüzde bilgisayar teknolojileri ve yapay zekâ algoritmalarındaki gelişimle ortaya çıkan yeni yöntemler daha hizlı ve daha verimli çözümler sunmaktadır. Pek çok disiplin gibi yapı mühendisliği de optimizasyon yöntemlerindeki gelişmelerden ve bu yöntemlerin sunduğu imkanlardan etkilenmiştir. Önceleri deneme yanılma yöntemine başvurularak yapılan ve tasarımı gerçekleștiren mühendisin tecrübesi ile çözüm bulma süresinin doğrudan ilintili olduğu problem çözümleri, gelişen optimizasyon yöntemleri sayesinde optimizasyon algoritmalarına ve uzman sistemlere devredilmeye başlanmıştır.

Klasik optimizasyon yöntemleri, nispeten küçük arama alanlarındaki optimizasyon problemleri için uygulanabilir olsalar da tasarım değişkeni sayısı yani problemin boyutu arttıkça, büyüyen arama alanıyla birlikte performansların kaybetmektedirler. Problemin çözümü için geçen süre arttıkça tasarımcılar açısından pratikliğini yitiren yöntemler, yeni optimizasyon yöntemlerinin gelişmesine de zemin hazırlamıștır [1]. Metasezgisel algoritmalar bu noktadaki ihtiyaca pratik bir çözüm üretmektedirler. Metasezgisel (metaheuristic) kelimesi, Yunanca yeni strateji bulma sanatı anlamına gelen "heuriskein" sözcügünün üst seviye anlamındaki "meta" ön ekiyle birleşmesinden oluşmuș ve özel optimizasyon problemlerinin çözümü için ortaya konulmuş, belirli stratejileri temel alan üst düzey genel metodolojileri ifade etmektedir [2]. $\mathrm{Bu}$ algoritmalar doğadan, fizikten, bir canlının av ararken ya da eş seçerken sergilediği davranışlardan, matematikten ve birçok diğer alandan belirli stratejileri temel almaktadırlar. İham kaynakları neticesinde ortaya çlkan strateji, tasarım değișkenlerinin sınırlarıyla oluşturulan arama alanındaki en iyi sonucu bulmaya çalışırken, rehber niteliğinde görev yapmaktadır. Metasezgisel algoritmalar esin kaynaklarına göre; sürü tabanll, evrimsel ve fiziksel algoritmalar olmak üzere üç ana kategoride değerlendirilebilirler [3]. En çok bilinen sürü tabanlı algoritmalar Parçacık Sürü Optimizasyonu [4], Karınca Kolonisi [5], Yapay
Arı Kolonisi [6], Ateș Böceği [7] ve Cuckoo Arama Algoritması [8]; evrimsel temelli algoritmalardan en yaygın kullanılanlar Genetik Algoritma [9], Diferansiyel Evrim [10], Evrim Stratejisi [11] ve Genetik Programlama [12]; fizik tabanlı algoritmaların en bilinenleri ise Tavlama Benzetimi [13], Büyük Patlama Büyük Çöküş [14], Kara Delik [15] ve Işın Optimizasyonu [16]'dur.

Yapısal optimizasyon kavramı ilk defa Schmit [17] tarafından yapılan bir çalıșma ile ortaya konulmuştur. Yeni bir yapı mühendisliği dalı olarak görülen bu alan, yapısal tasarım problemlerini bir karar verme problemi olarak yeniden kurgulamaktadır. Karar verme, kişinin mevcut seçenekler arasında en iyi olana yöneldiği bilişsel bir süreci ifade etmektedir. Karar verme problemleri, belirlenmiş sınırlar altında çözümün kalitesini temsil eden bir amaç fonksiyonunu en aza indirgeyecek ya da en yükseğe çıkaracak şekilde modellenir. Tasarım değișkenleri, problemdeki kaynağın miktarını ve bazı faaliyetlerin düzeylerini ifade eder. Karar verme probleminin optimum çözümü, tasarım değişkenlerinin amaç fonksiyonunu en iyiye getirdiği değeri bulmayı hedefler. Yapısal tasarım süreci matematiksel olarak modellenirken; tasarım değișkenleri genellikle yapısal elemanın kesitsel özelliklerini, kısıtlar ise genellikle meydana gelen yer değiştirme ve gerilmedeki sınırlamaları ifade etmektedir. Amaç fonksiyonu genellikle yapının maliyetini en aza indirecek șekilde seçilmektedir [18].

İlgili literatür incelendiğinde, çelik yapıların optimizasyonu alanında pek çok çalışma yapıldığı görülmektedir. Saka [19] tarafından yapılan çalışmada matematik tabanlı bir algoritma ile AISC (American Institute of Steel Construction) yönetmeliğindeki gerilme ve yer değiștirme kısıtları kullanılarak çelik çerçeve sistemlerin boyutlandırılması gerçekleştirilmiştir. İlgili çalışma amaç fonksiyonu ve kısitların olusturularak algoritmalara tanıtılması gibi konularda pek çok araștırmacıya yol göstermiștir. Daloğlu ve Armutçu [20] tarafindan yapılan çalıșmada TS648 esas alınarak düzlem çelik çerçeve sistemler genetik algoritma ile boyutlandırılmıștır. Daloğlu ve Aydın [21] genetik algoritma ile düzlem kafes sistemleri optimize etmişlerdir. Kameshki ve Saka [22] tarafından, yarı rijit bağlanmış çerçeveler için P$\Delta$ etkisini de dikkate alarak lineer olmayan bir 
yaklașım ile boyut optimizasyonu yapılmıștır. Hayalioğlu ve Değertekin [23] tarafından yapılan çalışmada yarı rijit bağlı doğrusal olmayan çelik çerçeveler genetik algoritma ile optimize edilmiștir. Kaveh ve Talatahari [24] tarafından, birçok algoritma ile düzlem çelik çerçevelerin optimizasyonu gerçekleștirilmiștir. Saka [25] tarafından yapılan çalışmada Harmoni Arama Algoritması ile BS-5950 yönetmeliğini kullanılarak düzlem çelik çerçeve optimizasyonu gerçekleştirmiştir. Benzer şekilde Toğan [26] tarafindan TLBO (Teaching-Learning Based Optimization) algoritması kullanılarak AISC yönetmeliğinin LRFD (Load and Resistance Factor Design) tasarım prensibi için AISC'de listelenmiş $\mathrm{W}$ profillerden optimum seçimler yaptırılmıştır. TLBO algoritması, Karınca Kolonisi Optimizasyonu, Harmoni Arama Algoritması, Geliştirilmiş Karınca Kolonisi Optimizasyonu yöntemleri ile karşılaştırılarak güçlü bir algoritma olduğu ortaya konmuştur.

Kaynaklı birleşimlerin optimizasyonuna dair literatürde en çok bilinen problem Ragsdell ve Phillips [27] tarafından ortaya konulmuştur. Problemde kurulum, kaynak işçiliği ve malzeme maliyetlerinin toplamından oluşan amaç fonksiyonunun minimize edilmesi hedeflenmiştir. Tanıtılan kaynaklı kiriş problemi Geometrik Programlama yöntemi ile optimize edilmiştir. $\mathrm{Bu}$ problem farklı araștırmacılar tarafından da yaygın olarak kullanılmıştır [28, $29,30,31,32]$. Bunun neticesinde yeni geliştirilen algoritmaların eski algoritmalar ile mukayesesi noktasında bir test fonksiyonu olarak kabul görmüştür.

Alberdi vd. [33] tarafından çelik çerçevelerin optimize edildiği çalışmada, birleşimler için dört farklı topoloji tanımlanıp çerçeve optimizasyonu ile birlikte birleşim topoloji optimizasyonu da gerçekleștirmiştir. Jin vd. [34] tarafından yapılan çalışmada, çerçeve ile birlikte kaynaklı birleşimlerin de optimizasyonunu sağlamak amacıyla, maliyet hesabına dayanan ve literatürdeki diğer çalışmalar ile kıyaslandığında nispeten kolay bir yöntem önerilmiștir. Çalışmada Genetik Algoritma kullanılmış ve Japon deprem yönetmeliği dikkate alınmıştır.

Çelik yapıların optimizasyonuna dair literatür incelendiğinde çalışmalardaki genel eğilimin yapı sistemlerinin genel hatları ile optimizasyonu olduğu gözlemlenmiştir. $\mathrm{Bu}$ bağlamda, yapı elemanları için profil listelerinden uygun profillerin seçtirilmesi gibi yöntemlerle pek çok çalışma yapılmıștır [22, 23, $25,26]$. Bu tür çalışmalarda birleşim hesapları bazı kabullerle sinırlı kalarak bulonlu ya da kaynaklı birleşim detayları için optimizasyon yapılması yerine analizlerin genellikle rijit ya da yarı rijit kabul ekseninde ilerlediği görülmüştür.

Bu çalışmada; Jaya, TLBO ve Sinüs-Kosinüs (SCA) algoritmaları kullanılarak çelik yapıların kaynaklı birleşimlerinin optimum tasarımının gerçekleștirilmesi, metasezgisel algoritmalar ile elde edilen sonuçların karşılaştırılarak algoritmaların birbirine göre avantajlı ve dezavantajlı yönlerinin belirlenmesi ve bu çalışmada sunulan Adil Ceza Yöntemi'nin kısıtlı optimizasyon problemlerinin çözümünde kullanılabilirliğinin araştırılması amaçlanmıştır. $\mathrm{Bu}$ amaçlar doğtultusunda ÇYTHYDE-2018 yönetmeliğinde belirtilen gereklilikleri sağlayan üç adet sayısal model oluşturularak yönetmelikte tanımlanan iki farklı tasarım yöntemi ve üç farklı popülasyon büyüklüğü için 54 ayrı analiz yapılmıştır.

\section{Materyal ve Metot}

Bu çalışmada, detayları bu kısımda verilmiş olan köşe kaynaklı birleşimlerin kaynak alanlarının optimize edilmesi amaciyla Jaya, TLBO ve SCA algoritmaları kullanılmıștır. Analizler Çelik Yapıların Tasarım, Hesap ve Yapımına Dair Esaslar - 2018'de (ÇYTHYDE-2018) tanımlanan yük ve dayanım katsayıları ile tasarım (YDKT) ve güvenlik katsayıları ile tasarım (GKT) yöntemleri esas alınarak gerçekleştirilmiştir.

\section{1. ÇYTHYDE-2018'e Göre Köşe Kaynaklı Birleşimlerin Tasarımı}

CYTHYDE-2018'e göre birleșen çelik elemanlar arasındaki açı $60^{\circ}$ ile $120^{\circ}$ aralığında olan kaynaklar köşe kaynak olarak değerlendirilerek tasarlanacaktır. Köşe kaynaklarda belirlenecek minimum etkin kalınlık, hesaplanmış olan kuvvetin emniyetli şekilde aktarılmasına

Tablo 1. Köşe kaynakların minimum kalınlıkları [35].

\begin{tabular}{cc}
$\begin{array}{c}\text { Bileșen İnce Elemanın } \\
\text { Kalınlığı, t (mm) }\end{array}$ & $\begin{array}{c}\text { Minimum Köşe Kaynak } \\
\text { Kalınlığı, }{ }^{\text {a }} \text { (mm) }\end{array}$ \\
\hline$t \leq 6$ & 3,0 \\
$6<t \leq 19$ & 3,5 \\
$13<t \leq 19$ & 4,0 \\
$19<t$ & 5,5 \\
\hline
\end{tabular}

\footnotetext{
a:Tek geçişli kaynaklar kullanılmalıdır.
} 
yetecek minimum kalınlıktan ve Tablo 1'de verilen minimum kalınlıklardan daha az seçilemez [35].

Maksimum kaynak kalınlığı için kaynak ile birleştirilen elemanın kenar kalınlığı t olmak üzere şu şartlara uyulacaktır: Kaynaklanan ince elemanın kenar kalınlığı olan t, 6 mm'den küçük ise kaynak kalınlığı a, 0,7t'den daha büyük seçilemez. Kaynaklanan ince elemanın kenar kalınlığı olan t, $6 \mathrm{~mm}$ 'den büyük ise kaynak kalınlığı a, 0,7(t-2) mm'den daha büyük seçilemez. Köșe kaynakları için minimum etkin uzunluk, kaynak kalınlığı olan a'nın 6 katından veya $40 \mathrm{~mm}$ 'den daha küçük seçilmemelidir. Çelik elemanların kaynaklı uç birleşimlerindeki ekin kaynak uzunluğu aşağıdaki şartlar göz önüne alınarak denklem (1), (2) ve (3) ile hesaplanmaktadır [35].

$$
\begin{gathered}
L \leq 150 a \text { için } \quad L_{e}=L \\
150 a<L \leq i c ̧ i n \quad L_{e}=\beta L \\
\beta=1.2-0,0014(L / a) \leq 1.0 \\
400 a<L i c ̧ \text { in } \quad L_{e}=250 a
\end{gathered}
$$

Bu denklemlerde, $L$ kaynağın uzunluğu, $L_{e}$ etkin kaynak uzunluğu, $a$ kaynak etkin kalınlığ,$\beta$ ise azaltma katsayısıdır. Kaynaklı birleșim noktalarının tasarım dayanımları $\left(\phi R_{n}\right)$ veya güvenli dayanımları $\left(R_{n} / \Omega\right)$ esas metalin çekme ve kayma etkisindeki kırılma sınır durumları ve kaynak metalinin kırılma sınır durumları hesaplanarak kritik olan değer esas alınarak yapılacaktır. Esas metalin karakteristik dayanımı $R_{n B M}$ ve kaynak metalinin karakteristik dayanımı $R_{n w}$ sırasıyla denklem (4) ve (5) ile hesaplanacaktır [35].

$$
\begin{aligned}
R_{n B M} & =F_{n B M} A_{B M} \\
R_{n w} & =F_{n w} A_{w e}
\end{aligned}
$$

$\mathrm{Bu}$ denklemlerde; $F_{n B M}$ esas metal için karakteristik gerilme, $F_{n w}$ kaynak metali için karakteristik gerilme, $A_{B M}$ kaynak boyunca esas metalin yüzey alanı, $A_{w e}$ etkin kaynak alanıdır. $\phi$, $\Omega, \quad F_{n B M}$ ve $F_{n w}$ için alınacak değerler ve kullanılacak yöntemler Tablo 2'de verilmiștir. Köşe kaynakların karakteristik gerilmesi olan $F_{n w}$ kaynağın boyuna ekseninin kuvvetin doğrultusuyla arasındaki açı dikkate alınmadan Tablo 2'den kullanılabilir [35].

\section{2 Çalışmada Kullanılan Metasezgisel Algoritmalar}

$\mathrm{Bu}$ çalıșmada kullanılmak üzere güncel ve popüler üç farklı metasezgisel algoritma seçilmiştir. Algoritmalar seçilirken birbirinden farklı çalışma prensiplerine sahip olmalarına dikkat edilmiștir. $\mathrm{Bu}$ bağlamda; TLBO algoritması çift fazlı ve parametresiz, Jaya algoritması tek fazlı ve parametresiz, SCA ise tek fazlı ve parametrelidir. İlgili algoritmaların hesaplamalarına ilişkin detaylar, akış diyagramları ve örnek problem çözümleri ayrıntılı olarak Sezer [36] tarafından verilmiştir.

\section{Jaya Algoritması}

Rao [37] tarafından geliştirilmiştir. Jaya kelime

\begin{tabular}{|c|c|c|c|c|c|}
\hline \multicolumn{6}{|c|}{ KÖŞE KAYNAKLAR } \\
\hline $\begin{array}{c}\text { Yük Tipi ve } \\
\text { Kaynak Eksenine } \\
\text { Göre Doğrultusu }\end{array}$ & İlgili Metal & $\phi \operatorname{ve} \Omega$ & $\begin{array}{c}\text { Karakteristik } \\
\text { Gerilme } \\
\left(F_{n B M} \text { veya }\right. \\
\left.F_{n w}\right)\end{array}$ & $\begin{array}{c}\text { Etkin } \\
\text { Alan } \\
\left(A_{B M} \text { veya }\right. \\
\left.A_{w t}\right)\end{array}$ & $\begin{array}{c}\text { Kaynak Metali } \\
\text { Gerekli Dayanım } \\
\text { Düzeyi }\end{array}$ \\
\hline \multirow[t]{2}{*}{ Kesme } & Esas Metal & \multicolumn{3}{|c|}{ Bölüm 13.4} & Bölüm 13.2.6 \\
\hline & Kaynak Metali & $\begin{array}{l}\phi=0,75 \\
\Omega=2,00\end{array}$ & $0,60 F_{E}$ & $\begin{array}{c}\text { Bölüm } \\
\text { 13.2.2.1 }\end{array}$ & \\
\hline $\begin{array}{l}\text { Kaynak eksenine } \\
\text { paralel çekme ve } \\
\text { basınç }\end{array}$ & \multicolumn{4}{|c|}{$\begin{array}{l}\text { Kaynak eksenine paralel çekme ve basınç etkilerinin kaynak } \\
\text { tasarımında göz önüne alınmasına gerek yoktur. }\end{array}$} & \\
\hline
\end{tabular}
olarak Sanskritçe'de zafer anlamına gelmektedir. Diğer pek çok metasezgisel algoritmadan farklı olarak herhangi bir doğa olayı, sosyal hayat,

Tablo 2. Köșe kaynakların hesabında kullanılacak değerler ve ÇYTHYDE-2018 yönetmeliği içerisinde esas alınacak bölümler [35]. 
hayvan davranışları gibi bir esin kaynağı bulunmamaktadır. Algoritma, başarıya yaklaşmaya (en iyi çözüme ulaşmaya) ve başarısızlıktan kaçmaya (en kötü çözümden uzaklaşmaya) dayanan bir matematiksel felsefe ile çalışmakta olup algoritmaya özgü bir parametre içermemektedir. Tek fazlı yapıdadır. Yani her iterasyon için popülasyondaki elemanlar bir defa güncellenmektedir. Popülasyon güncellemesi denklem (6) ile gerçekleştirilmektedir.

$$
\begin{aligned}
X_{j, k, i}^{\prime} & =X_{j, k, i}+r_{1, j, i}\left(X_{j, b e s t, i}-\left|X_{j, k, i}\right|\right) \\
& -r_{2, j, i}\left(X_{j, w o r s t, i}-\left|X_{j, k, i}\right|\right)
\end{aligned}
$$

Yukarıdaki denklemde; $X_{j, k, i} i$. iterasyonda $k$. çözümün $j$. değişkeni (güncellenecek değişken), $X^{\prime}{ }_{j, k, i} X_{j, k, i}$ 'in denklem (6) ile güncellenmiş hali, $r_{1, j, i} i$. iterasyondaki $j$. değişken için $[0,1]$ aralığındaki rastsal sayı, $r_{2, j, i}: i$. iterasyondaki $j$. değişken için $[0,1]$ aralığındaki rastsal sayl, $X_{j, \text { best }, i}$ en iyi çözümü veren çözüm kümesinin $j$. değişkeni, $X_{j, w o r s t, i}$ ise en kötü çözümü veren çözüm kümesinin j. değișkenidir.

\section{Öğretme - Öğrenme Tabanlı Optimizasyon (TLBO)}

Öğretme - Öğrenme Tabanlı Optimizasyon (TLBO: Teaching - Learning Based Optimization), bir derslik içerisindeki öğretme ve öğrenme sürecini taklit eden popülasyon tabanlı bir algoritmadır. Rao vd. [38] tarafından geliștirilmiştir. Derslikteki öğrenci grubu popülasyon olarak kabul edilmektedir. Öğrencilere okutulan farklı dersler optimizasyon probleminin farklı tasarım değişkenlerini ifade etmektedir. TLBO algoritmasının pek çok geliştirilmiş ya da elitleștirilmiş çeşidi bulunmaktadır. Temel TLBO algoritmasında popülasyonun en iyi çözüm değerine sahip elemanı öğretmen olarak kabul edilir. TLBO, öğretmen aşaması ve öğrenci așaması olmak üzere iki ayrı faza sahiptir. Öğretmen aşamasındaki popülasyonu geliştirmek için denklem (7), öğrenci aşamasındaki popülasyonu geliştirmek için ise minimizasyon problemlerinde denklem (8) ve (9) kullanılır. İki fazlı yapısından dolayı bir iterasyon için her eleman iki defa güncellenmektedir. Bu durum daha az iterasyonla çözüme ulaşmayı sağlarken her bir iterasyon için geçen süreyi uzatmaktadır. Algoritmanın kendine özgü parametreleri bulunmamaktadır.

$$
X_{j, k, i}^{\prime}=X_{j, k, i}+\text { Difference_Mean }{ }_{j, k, i}
$$

Bu denklemde; $i$ iterasyon, $X_{j, k, i} i$ iterasyonda $k$. çözümün $j$. değișkeni ( $k$. öğrencinin aldığı j. derse karşılık gelmektedir), $\quad X_{j, k, i}^{\prime}$ popülasyondaki her bir $X_{j, k, i}$ değerinin denklem (7) ile güncellenmiş hali, Difference_Mean ${ }_{j, k, i}$ ise her ders için öğretmenin sonucundan mevcut ortalama sonucun $T_{f}$ mislinin çlkarılıp, elde edilen değerin $[0,1]$ aralığında rastsal bir sayı ile çarpılmasıyla bulunur. Burada $T_{f}$ değeri 1 veya 2 olarak kendiliğinden seçilir.

$$
\begin{aligned}
& X^{\prime \prime}{ }_{j, P, i}=X^{\prime}{ }_{j, P, i}+r_{i}\left(X^{\prime}{ }_{j, P, i}-X_{j, Q, i}^{\prime}\right) \\
& \text {; } X^{\prime} \text { total-P,i}<X^{\prime}{ }_{\text {total }-Q, i} \\
& X^{\prime \prime}{ }_{j, P, i}=X^{\prime}{ }_{j, P, i}+r_{i}\left(X^{\prime}{ }_{j, Q, i}-X_{j, P, i}^{\prime}\right) \\
& ; X^{\prime}{ }_{\text {total }-Q, i}<X^{\prime} \text { total-P,i }
\end{aligned}
$$

Yukarıdaki denklemlerde, $P$ ve $Q$ rastgele seçilmiş iki öğrencidir. Burada $X_{\text {total }-P, i}^{\prime}$ ve $X_{\text {total-Q,i}}^{\prime}$ değerleri $X_{\text {total-P,i}}$ ve $X_{\text {total-Q, },}{ }^{\prime}$ in yani öğrenci matrisindeki popülasyonun öğretmen aşamasında güncellenmiş versiyonunun amaç fonksiyonundan geçmiş halidir.

\section{Sinüs-Kosinüs Algoritması (SCA)}

Sinüs - Kosinüs Algoritması Mirjalili [39] tarafından geliștirilen matematik tabanlı bir metasezgisel algoritmadır. SCA'da diğer sürü tabanlı algoritmalar gibi keşif (global arama) ve sömürü (keşfedilmiş global optimumun etrafında derinlemesine lokal arama) olmak üzere iki ana ilke etrafında çalışmaktadır. Algoritmanın arama mekanizması Şekil 1'de gösterilmiştir. $\mathrm{Bu}$ çalışmada kullanılan diğer algoritmaların aksine SCA, çalışmak için kendine özgü bazı parametrelere ihtiyaç duymaktadır. Bu durum doğru parametrelerin seçilebilmesi için bir dizi deneme ihtiyacını ortaya çıkarmaktadır. SCA için popülasyon güncellemesi denklem (10) ile yapılmaktadır.

$$
X_{i}^{t+1}=\left\{\begin{array}{cc}
x_{i}^{t}+r_{1} * \sin \left(r_{2}\right) *\left|r_{3} * P_{i}^{t}-X_{i}^{t}\right| \\
; \quad r_{4}<0,5 \\
x_{i}^{t}+r_{1} * \cos \left(r_{2}\right) *\left|r_{3} * P_{i}^{t}-X_{i}^{t}\right| \\
; \quad r_{4} \geq 0,5
\end{array}\right.
$$

Bu denklemde; $P_{i}^{t}$ elde edilen en iyi çözümün ilgili tasarım değișkeni, $r_{1}$ bir sonraki pozisyon bölgesi veya hareket yönünü belirlemektedir 
$\left(r_{1}=a-t a / T\right)$. Keşif ve sömürü arasındaki dengeyi sağlamak için kullanılmaktadır yani lokal ekstremum noktalarında takılmayı önleme görevine sahiptir. $a$ algoritma parametresi, $T$ toplam iterasyon sayısı, $t$ içinde bulunulan iterasyon numarasıdır. $r_{2}$ içe ya da dışa doğru hareket miktarını belemektedir. $([0,2 \pi]$ aralığında radyan cinsinden rastgele açı ölçüsüdür.) $r_{3}$ stokastik ağırlık katsayısı ( $r_{3}>1$ ise stokastik önemli $r_{3}<1$ ise stokastik daha etkisizdir.) $r_{3}=b^{*}[0,1]$ olarak tanımlandığında $\mathrm{b}$ değeri SCA için bir çalışma parametresi olarak ortaya çıkmaktadır. Rastlantısallığa eşit oranda şans vermek için $r_{3}$ parametresi $[0,2]$ aralığında rastgele sayı olarak seçilebilir. $r_{4}$ denklemdeki sin-cos arası geçişi sağlayan parametredir. Sinüs ve kosinüs kullanımına eşit şans vermek için $[0,1]$ aralığında rastgele sayı olarak seçilebilir.

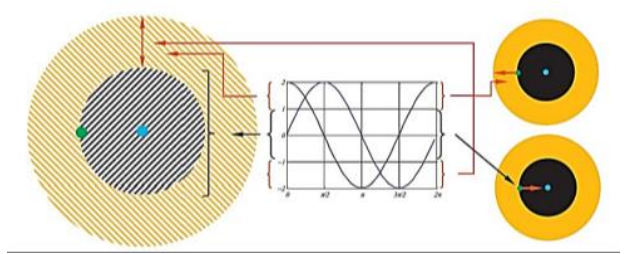

Şekil 1. SCA için arama modeli [39].

2.3 Problemlerin Tanıtımı ve Optimizasyon Modellerinin Oluşturulması

$\mathrm{Bu}$ çalışmasında temel birleşim modeli olarak HEA 360 profilden teșkil edilmiş kirișin HEB400 profilden teşkil edilmiş kolona köşe kaynak ile bağlantısı seçilmiştir. İlgili modelde, HEA 360 profil; başlık dış, başlık iç ve gövde kaynak grupları ile kolona köşe kaynaklar vasıtasıyla bağlanmaktadır. Her bir kaynak grubu için kaynak kalınlıkları ve uzunlukları eşit kabul edilmiştir. Bunun sebebi kaynak gruplarındaki asimetrik ölçülerin, kaynak düzleminde eksantrisite oluşturması neticesinde arama uzayında optimumdan uzaklaşacak bölgeler yaratmasıdır. $\mathrm{Bu}$ durumun optimizasyon algoritmalarının performansını olumsuz etkilememesi için kaynak grupları simetrik olarak boyutlandırılmıștır. Birleşim; moment $(M)$, kesme kuvveti $(V)$ ve normal kuvvet $(N)$ etkisi altındadır. Seçilen birleşim modeline ait genel durum Şekil 2'de gösterildiği gibidir. Çelik malzeme sınıfı olarak tüm profiller için S275 tercih edilmiştir. Kaynak metali için $F_{E}=480$ $\mathrm{N} / \mathrm{mm}^{2}$ seçilmiştir. Sayısal modellerde kullanılacak bütün yükler sabit yük olarak kabul edilmiştir. Genel hali tanıtılan birleșim modelinden, farklı yükleme durumları için üç adet sayısal model (SM) oluşturulmuştur. Birleşim modeli, yük ve dayanım katsayıları ile tasarım (YDKT) ve güvenlik katsayıları ile tasarım (GKT) yöntemleri için; moment etkin, normal kuvvet etkin ve kesme kuvveti etkin yükleme durumları altında çözülecektir. Sayısal modeller için isimlendirme Tablo 3'de, farklı yükleme durumlarını temsil eden yük dağılımları ise Tablo 4'de verilmiştir. Yük ve momentler birleşimin kapasitesini mümkün olduğunca yüksek oranda kullanacak şekilde seçilmiştir.

Tablo 3. Tasarım esasları ve yükleme durumlarına göre sayısal modeller.

\begin{tabular}{cccc}
\hline \multirow{2}{*}{$\begin{array}{c}\text { Tasarım } \\
\text { Prensibi }\end{array}$} & \multicolumn{3}{c}{ Yükleme Durumları } \\
\cline { 2 - 4 } & $\begin{array}{c}\text { Moment } \\
\text { Etkin }\end{array}$ & $\begin{array}{c}\text { Normal } \\
\text { Kuvvet } \\
\text { Etkin }\end{array}$ & $\begin{array}{c}\text { Kesme } \\
\text { Kuvveti } \\
\text { Etkin }\end{array}$ \\
\hline GKT & SM-1A & SM-2A & SM-3A \\
YDKT & SM-1B & SM-2B & SM-3B \\
\hline
\end{tabular}

Tablo 4. Yükleme durumları için kuvvet dağılımları.

\begin{tabular}{cccc}
\hline $\begin{array}{c}\text { Yükleme } \\
\text { Durumu }\end{array}$ & $\boldsymbol{M}(\boldsymbol{k N M})$ & $\boldsymbol{N}(\boldsymbol{k N})$ & $\boldsymbol{V}(\boldsymbol{k N})$ \\
\hline $\begin{array}{c}\text { Moment } \\
\text { Etkin }\end{array}$ & 80 & 10 & 10 \\
$\begin{array}{c}\text { Normal } \\
\text { Kuvvet Etkin }\end{array}$ & 10 & 220 & 10 \\
$\begin{array}{c}\text { Kesme } \\
\text { Kuvveti } \\
\text { Etkin }\end{array}$ & 10 & 10 & 100 \\
\end{tabular}

\section{Tasarım Değişkenleri}

Tüm sayısal modellerde başlık dış, başlık iç ve gövde olmak üzere üç adet kaynak grubu bulunmaktadır. Optimizasyon algoritmalarının verimsiz bölgelerde arama yapmasının önüne geçilmesi maksadıyla her bir kaynak grubu için eşit kaynak kalınlığı ve eşit kaynak uzunluğu seçilmiştir. Yani her şartta kaynak alanları $\mathrm{x}$ ve $\mathrm{y}$ eksenine göre simetriktir. Bu sayede kaynak düzlemindeki eksantrisitenin önüne geçilmiştir. 

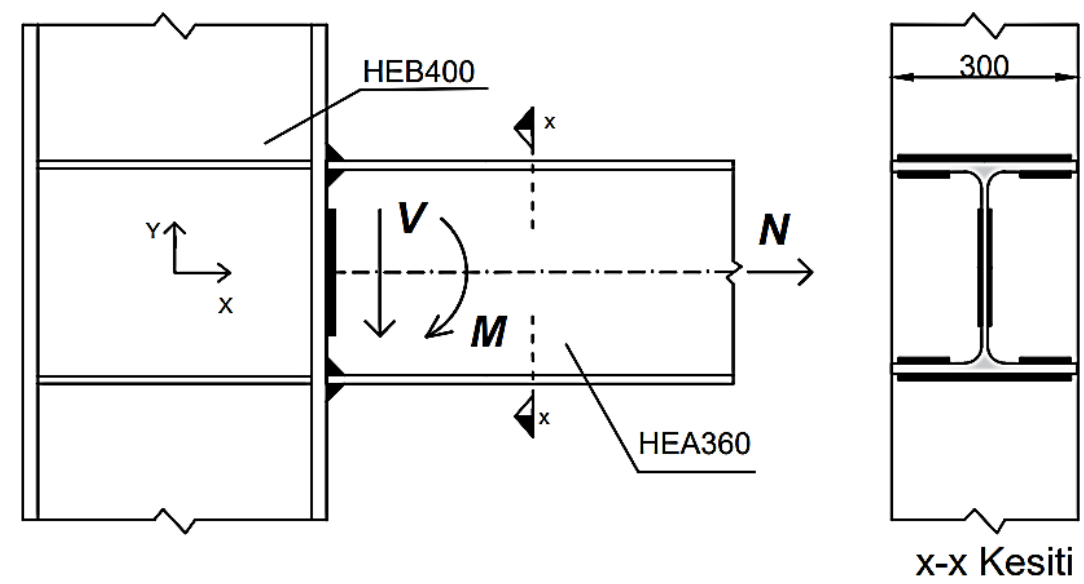

Şekil 2. Birleşim modelinin genel görünümü.

Bunun sonucu olarak her bir kaynak grubu için bir kaynak kalınlığı ve bir kaynak uzunluğu olmak üzere toplamda altı adet tasarım değișkeni ortaya çıkmıștır. İlgili tasarım değișkenleri Tablo 5'de açıklanarak Șekil 3'de gösterilmiștir.

Tablo 5. Tasarım değișkenleri.

\begin{tabular}{|c|c|}
\hline $\begin{array}{l}\text { Tasarım } \\
\text { Değișkeni }\end{array}$ & Açıklama \\
\hline$a_{1}$ & $\begin{array}{l}\text { Başlık dış kaynak grubu için } \\
\text { kaynak kalınlığı. }\end{array}$ \\
\hline$a_{2}$ & $\begin{array}{l}\text { Başlık iç kaynak grubu için kaynak } \\
\text { kalınlığı. }\end{array}$ \\
\hline$a_{3}$ & $\begin{array}{l}\text { Gövde kaynak grubu için kaynak } \\
\text { kalınlığı. }\end{array}$ \\
\hline$L_{1}$ & $\begin{array}{l}\text { Başlık dış kaynak grubu için } \\
\text { kaynak uzunluğu. }\end{array}$ \\
\hline$L_{2}$ & $\begin{array}{l}\text { Başlık iç kaynak grubu için kaynak } \\
\text { uzunluğu. }\end{array}$ \\
\hline$L_{3}$ & $\begin{array}{l}\text { Gövde kaynak grubu için kaynak } \\
\text { uzunluğu. }\end{array}$ \\
\hline
\end{tabular}

\section{Amaç Fonksiyonu}

Yapılan optimizasyonun nihai amacı minimum kaynak alanları ile maksimum faydanın sağlanmasıdır. Bu maksatla yönetmelikteki kısıt ve gerekliliklere uyarak, kaynaklardaki kullanım kapasitesinin \%100'e yaklaștırılması amaçlanmıştır. İlgili birleşim modeli için kaynak alanının minimizasyonu, kaynak kapasite kullanımının maksimizasyonu anlamına gelmektedir. Buradan hareketle, sayısal modellerin hepsinde bütün kısıt ve gerekliliklere uyan minimum kaynak alanı aranmaktadır. Dolayısıyla amaç fonksiyonu olarak toplam kaynak alanının minimizasyonu seçilmiștir.
Kısıtlı optimizasyon yöntemi için amaç fonksiyonu denklem (11)'de gösterilmiştir.

$\min F_{(n)}=\left(2 a_{1} L_{1}+4 a_{2} L_{2}+2 a_{3} L_{3}\right)+p_{(n)}$

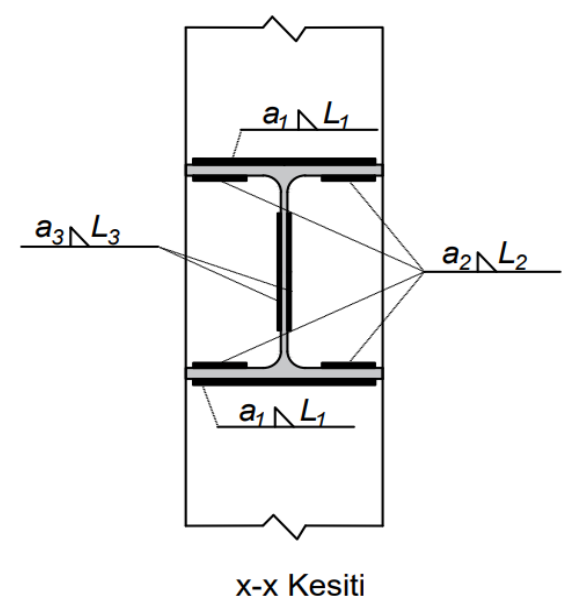

Şekil 3. Tasarım değişkenleri.

\section{Kisıtlar}

Optimize edilecek sayısal modeller GKT ve YDKT tasarım yöntemleri için ayrı iki süreç olarak kodlanmıștır. Güvenlik katsayıları ile tasarım ile yük ve dayanım katsayılarına göre tasarım yöntemlerinde kullanılan idealize edilmiș kısıt fonksiyonları Tablo 6'da gösterildiği gibidir. Kisitların kontrol edilmesine dair detaylar ve hesap prosedürleri Sezer [36] tarafından yapılan çalışmada verilmiştir. 
DEÜ FMD 24(70), 277-290, 2022

Tablo 6. GKT ve YDKT tasarım yöntemleri için kısıt fonksiyonları.

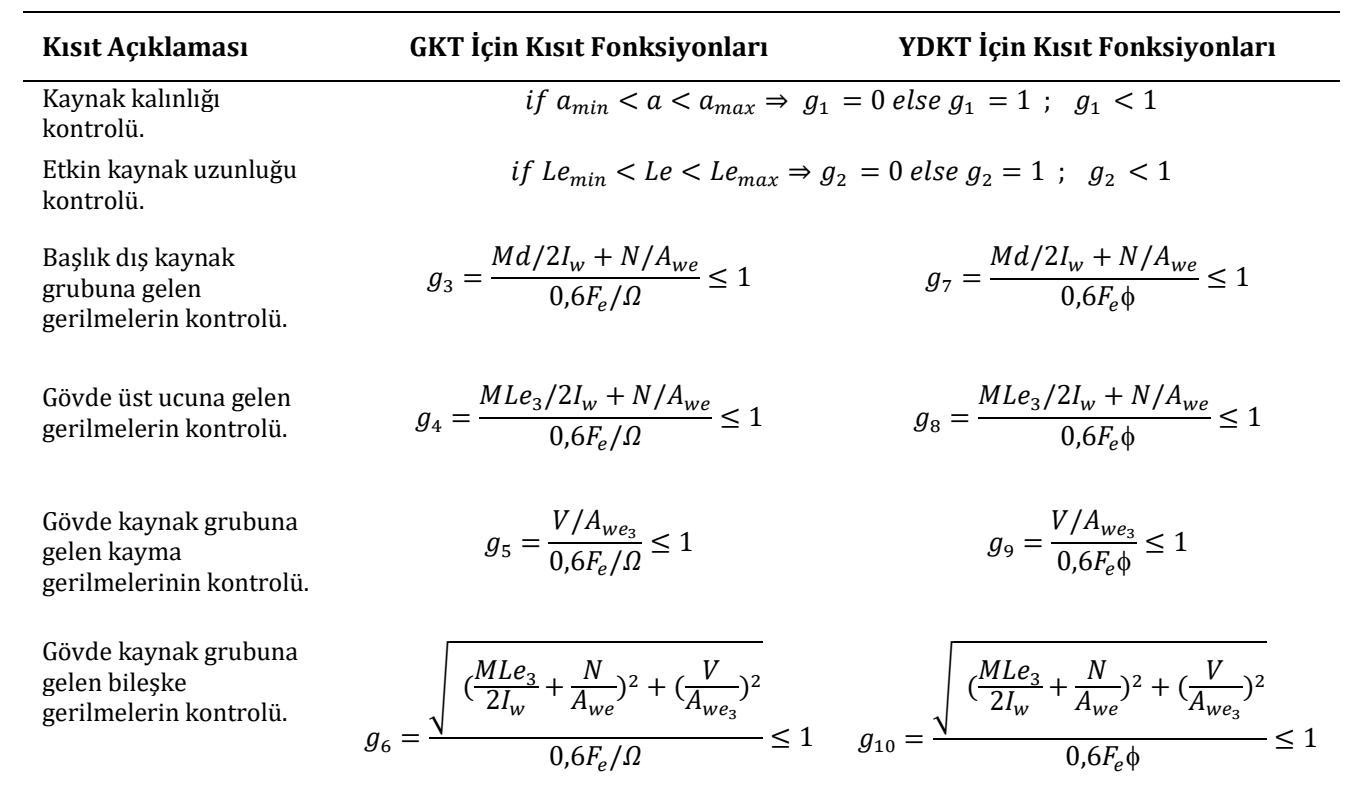

Bu tabloda, $a$ : kaynak kalınlığı, $F e$ : kaynak metalinin karakteristik çekme dayanımı, $\Omega$ : güvenlik katsayısı, $\phi$ : dayanım katsayısı, $I_{w}$ : toplam etkin kaynak dikişi alanının kirișin kuvvetli eksenine göre toplam atalet momenti, d: kirişin yüksekliği, $M$ : moment, $N$ : normal kuvvet, $V$ : kesme kuvveti, $L_{e}$ : etkin kaynak uzunluğu, $A_{w e}$ : etkin kaynak alanıdır.

\section{Adil Ceza Yöntemi ve Ceza Fonksiyonu}

Kısıtlı optimizasyon problemlerinin çözülebilmesi için problemin yapısına göre seçilebilecek pek çok farklı cezalandırma metodu bulunmaktadır. Bu çalışmada "Adil Ceza Yöntemi” olarak isimlendirilen özgün bir yöntem önerilmiştir. Adil Ceza Yöntemi, her bir popülasyon elemanının ihlal ettiği kısıt sayısı nispetinde cezalandırması fikrini temel almaktadır. Adaletli cezalar ile popülasyonun daha kısa sürede daha iyi yerlere gidebilmesi için imkân sağlanarak algoritmaların performansının arttırılması hedeflenmektedir. Adil Ceza Yöntemi'nde her bir kısıt her eleman için kontrol edilerek uygun olup olmadıkları kısıt kontrol vektörlerinde saklanır. Uygunluk kontrolü yapılırken temel bilgisayar mantığındaki ikili sistemden faydalanılır. İlgili kontrol mekanizması denklem (12)'de gösterilmiştir. Bu denklemde; $g_{k(n)}$ kisit kontrol vektörü (kısıtlar için kısıta uymama sayısı yani hata sayacı), $k$ kısıt numarası, $n$ popülasyon eleman numarasıdır.

$$
\begin{gathered}
g_{k(n)}=0 \text {; ilgili kısıta uyuluyorsa } \\
g_{k(n)}=1 \text {; ilgili kısıta uyulmuyorsa }
\end{gathered}
$$

Kısıt kontrolleri yapıldıktan sonra kısıt kontrol vektörleri toplanarak her bir popülasyon elemanının kısitları toplamda ne kadar ihlal ettiği elde edilerek $g_{\text {top }(n)}$ vektöründe saklanır. $\mathrm{Bu}$ işlem denklem (13)'de gösterilmiştir.

$$
g_{\text {top }(n)}=\sum_{x=1}^{k_{\max }}\left(g_{x(n)}\right)
$$

$g_{\text {top (n) }} \quad$ vektörü ceza fonksiyonunda bir parametre olarak kullanılır. İlgili ceza fonksiyonu denklem (14)'te verilmiştir. Amaç fonksiyonundaki tasarım değişkenlerinin çarpım durumunda olduğu optimizasyon problemlerinde, algoritma bütün tasarım değișkenlerini sıfıra götürdüğünde ceza verilemeyecektir. $\mathrm{Bu}$ sorunun önüne geçilebilmesi maksadıyla ceza fonksiyonuna toplam durumunda 1000 sabiti bulunmaktadır.

$$
p_{(n)}=k c_{k}\left(F_{(n)}+1000\right) * g_{t o p(n)}
$$


$\mathrm{Bu}$ denklemlerde; $p_{(n)}$ her bir eleman için verilecek ceza miktarı, $k$ kısıt no, $k c_{k}$ her bir kısıt için kısıt ceza çarpanı (Gerektiğinde kısıtlardan herhangi birisi için verilecek cezanın arttırılıp azaltılması amacıyla kullanılmaktadır.), $F_{(n)}$ ceza öncesi hesaplanmış amaç fonksiyonu değeri, $g_{\text {top }(n)}$ her bir eleman için kısıtların toplam ihlal edilme sayısıdır. Adil Ceza Yöntemine ilişkin detaylar Sezer [36] tarafından verilmiştir.

\section{Optimizasyon Algoritmaları İçin Belirlenen Parametreler}

Jaya ve TLBO algoritmaları algoritmaya özel herhangi bir parametreye ihtiyaç duymazken SCA'nın algoritmaya özel parametrelere gereksinimi vardır. Algoritmaya özel olmayan çalıștırma parametreleri her algoritma için ortak seçilmiştir. $\mathrm{Bu}$ parametreler; popülasyon büyüklüğü $(n)$, tasarım değişkeni sayısı $(d)$ iterasyon sayısı ( $T$ ), arama uzayının sınırlarını belirleyen her bir tasarım değişkeni için alt sınırlar $\left(p_{a l t}\right)$ ve her bir tasarım değiş̧keni için üst sınırlardır ( $\left.p_{\text {üst}}\right)$. Seçilen ortak parametreler Tablo 7'de verilmiștir. Farklı kıyaslama durumları elde edebilmek amacıyla üç farklı popülasyon büyüklüğü $(n)$ ile analiz yapılmıştır. Farklı yükleme durumları altında elde edilen 3 adet sayısal model, 2 farklı tasarım prensibi, 3 farklı popülasyon büyüklügü ve 3 farklı optimizasyon algoritması ile toplamda birbirinden farklı 54 adet analiz gerçekleştirilmiştir. Bütün algoritmaların global optimuma ulaşabilmesi amacıyla iterasyon sayısı

Tablo 7. Ortak çalıştırma parametreleri.

\begin{tabular}{cll}
\hline Sembol & Parametre Değeri \\
\hline$n$ & 250,500 ve 1000 \\
\hline$d$ & 6 & \\
\hline$T$ & 1000 & $3 \mathrm{~mm}$ \\
\hline$p_{\text {alt }}$ & $a_{1}, a_{2}$ ve $a_{3}$ için & $20 \mathrm{~mm}$ \\
\hline$p_{\text {üst }}$ & $L_{1} L_{2}$ ve $L_{3}$ için & $15 \mathrm{~mm}$ \\
& $a_{1} a_{2}$ ve $a_{3}$ için & $300 \mathrm{~mm}$ \\
& $L_{1}$ için & $118 \mathrm{~mm}$ \\
& $L_{2}$ için & $261 \mathrm{~mm}$ \\
\hline
\end{tabular}

(T) mümkün olduğunca büyük seçilmiştir. Arama uzayının sınırlarını belirleyen parametreler olan $p_{\text {alt }}$ ve $p_{\text {üst }}$ algoritmaların gereksiz aramaların yapılacağı bölgelerden mümkün olduğunca uzak tutacak kadar dar, çözümü içerebilecek bölgelere mümkün olduğunca kapsayacak kadar geniş bir aralıkta seçilmeye çalışılmıştır.

SCA için yukarıda açıklanan ortak çalıșma parametrelerine ek olarak algoritmaya özel bazı parametrelere de ihtiyaç duyulmaktadır. Bu çalışmada, $b$ parametresi rastlantısallığa eșit șans vermek amacıyla 2 olarak seçilmiştir. a parametresinin seçilebilmesi için bir dizi analiz yapılması ihtiyacı ortaya çıkmıştır. Bu sebeple $0,1 \leq a \leq 3,0$ aralığında bazı denemeler gerçekleștirilmiș ve nihayetinde en iyi sonuçların elde edildiği parametre olan $\mathrm{a}=0,5$ seçilmiştir.

\subsection{Algoritmaların Karşılaştırılması}

Her bir algoritma için, tüm sayısal modellerden popülasyon eleman sayıları $n=250, n=500$ ve $n=1000$ için bazı karşılaştırma parametreleri toplanmıștır. $\mathrm{Bu}$ parametreler, her biri 1000 iterasyonluk 10 çalıștırma için ulaşılan en iyi, en kötü ve ortalama kaynak alanı değerleri, standart sapmalar ve iterasyonların işlem süreleridir. İşlem süreleri her analiz için aynı bilgisayardan özdeș koșullarda alınmıștır. Analizlerde kullanılan bilgisayar İntel ${ }^{\circledR}$ Core $^{\mathrm{TM}}$ i3-3120M CPU @ 2,50 $\mathrm{GHz}$ işlemciye ve 8GB RAM belleğine sahip olup Windows 10 Home 64 bit isletim sistemi ile çalışmaktadır. Tüm analizler, Matlab [40] yazılım dilinde oluşturulmuş kodlar vasitasıyla gerçekleștirilmiștir. Bunlara ilaveten, karşılaştırmalar için 10 çalıştırmanın her bir iterasyonundaki amaç fonksiyonu değerlerinin ortalamaları elde edilerek iterasyon-toplam kaynak alanı grafikleri oluşturulmuştur.

\section{Bulgular}

Sayısal modeller optimizasyon algoritmaları ile çözümlenmiş ve elde edilen sonuçlar bu bölümde özetlenmiștir. Tüm Sonuçlar CYTHYDE-2018'e bağlı kalınarak tanımlanan tüm kısıtları sağlamaktadır. Tablo 8'de analizler neticesinde elde edilen en iyi sonuç değerleri verilmiștir. Bu tabloda $A_{w}$ toplam kaynak alanı, GS-1 başlık dış kaynak grubunun üst ucuna gelen normal gerilmelerin kapasite kullanımı, GS-2 gövde kaynak grubunun üst ucunda oluşan normal gerilmelerin kapasite kullanımı, GS-3 gövde kaynak grubuna gelen kayma gerilmelerinin kapasite kullanımı, GS-4 ise gövde 
DEÜ FMD 24(70), 277-290, 2022

Tablo 8. Elde edilen en iyi sonuç değerleri.

\begin{tabular}{|c|c|c|c|c|c|c|c|c|c|c|c|c|c|}
\hline$\sum_{n}$ & Alg. & $\begin{array}{c}A_{w} \\
\left(m^{2}\right)\end{array}$ & GS-1 & GS-2 & GS-3 & GS-4 & $\sum_{n}$ & Alg. & $\begin{array}{c}A_{w} \\
\left(m m^{2}\right)\end{array}$ & GS-1 & GS-2 & GS-3 & GS-4 \\
\hline \multirow{3}{*}{$\sum_{\infty}^{\sharp}$} & Jaya & 3955,36 & 1,00 & 0,13 & 0,22 & 0,25 & \multirow{3}{*}{ 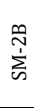 } & Jaya & 1977,21 & 1,00 & 0,74 & 0,17 & 0,76 \\
\hline & SCA & 3961,83 & 1,00 & 0,13 & 0,22 & 0,25 & & \multirow{2}{*}{$\begin{array}{c}\text { SCA } \\
\text { TLBO }\end{array}$} & 1981,86 & 1,00 & 0,74 & 0,17 & 0,76 \\
\hline & TLBO & 3955,25 & 1,00 & 0,13 & 0,22 & 0,25 & & & 1975,99 & 1,00 & 0,74 & 0,17 & 0,76 \\
\hline \multirow{3}{*}{$\sum_{n}^{n}$} & Jaya & 3717,05 & 1,00 & 0,13 & 0,17 & 0,22 & \multirow{3}{*}{$\sum_{\omega}^{\infty}$} & Jaya & 1927,64 & 0,50 & 0,16 & 0,99 & 1,00 \\
\hline & SCA & 3720,53 & 1,00 & 0,13 & 0,17 & 0,22 & & SCA & 1923,27 & 0,51 & 0,16 & 0,99 & 1,00 \\
\hline & TLBO & 3716,73 & 1,00 & 0,13 & 0,17 & 0,22 & & TLBO & 1919,34 & 0,51 & 0,16 & 0,99 & 1,00 \\
\hline \multirow{3}{*}{$\sum_{\infty}^{\mathbb{N}}$} & Jaya & 2291,05 & 1,00 & 0,78 & 0,22 & 0,81 & \multirow{3}{*}{$\sum_{i}^{m}$} & Jaya & 1776,03 & 0,47 & 0,12 & 0,99 & 1,00 \\
\hline & SCA & 2299,11 & 1,00 & 0,78 & 0,21 & 0,81 & & SCA & 1780,83 & 0,47 & 0,12 & 0,99 & 1,00 \\
\hline & TLBO & 2290,19 & 1,00 & 0,78 & 0,22 & 0,81 & & TLBO & 1775,88 & 0,47 & 0,12 & 0,99 & 1,00 \\
\hline
\end{tabular}

kaynak grubuna gelen bileşke gerilmelerin kapasite kullanımıdır.

Algoritmalar tarafından elde edilen sonuçlar incelendiğinde; SM-1'de beklendiği şekilde başlık dış kaynak gurubunun dış ucuna gelen normal gerilmelerin kapasitesi (GS-1) neredeyse \%100 oranında kullanılmıştır. SM-2'de de GS-1 kapasitesi neredeyse \%100 kullanılırken gövdeye gelen bileșke gerilmelerin kapasitesinin (GS-4) de yüksek oranda kullanıldığı görülmektedir. Bu kapasite kullanımı kayma gerilmelerinden ziyade gövde kaynak grubunun dis ucuna gelen normal gerilmelerin kapasitesinin (GS-2) yüksek oranda kullanılmasından kaynaklanmaktadır. SM-3 için gövde bileșke kapasitesi (GS-4) neredeyse $\% 100$ oranında kullanılmaktayken ilgili kapasite kullanımı beklendiği şekilde gövde kayma gerilmesi kapasitesinin \%99 oranında kullanımından oluşmaktadır. Sonuçlar incelendiğinde, algoritmaların kaynak alanlarını minimize ederek, maksimum kapasite kullanım hedefine bașarılı bir şekilde ulaștıkları anlaşılmaktadır.

Tablo 9. Karşılaștırma parametreleri.

\begin{tabular}{|c|c|c|c|c|c|c|c|c|c|c|}
\hline \multirow[t]{2}{*}{$n$} & \multirow[t]{2}{*}{ Durum } & \multicolumn{3}{|c|}{ SM-1A } & \multicolumn{3}{|c|}{ SM-1B } & \multicolumn{3}{|c|}{ SM-2A } \\
\hline & & Jaya & SCA & TLBO & Jaya & SCA & TLBO & Jaya & SCA & TLBO \\
\hline \multirow{5}{*}{ 号 } & EI $\left(\mathrm{mm}^{2}\right)$ & 3955,28 & 3960,86 & 3955,25 & 3716,75 & 3724,01 & 3716,73 & 2290,66 & 2298,23 & 2290,19 \\
\hline & $\overline{\mathrm{x}}\left(\mathrm{mm}^{2}\right)$ & 4021,31 & 3971,43 & 3955,26 & 3776,97 & 3733,04 & 3716,73 & 2294,84 & 2305,16 & 2290,19 \\
\hline & $\mathrm{EK}\left(\mathrm{mm}^{2}\right)$ & 4231,91 & 3979,33 & 3955,29 & 4105,20 & 3744,39 & 3716,74 & 2322,69 & 2311,21 & 2290,20 \\
\hline & $\mathrm{S}$ & 101,92 & 6,29 & 0,01 & 131,62 & 7,36 & 0,00 & 9,86 & 3,59 & 0,00 \\
\hline & $\mathrm{t}_{\mathrm{w}}(\mathrm{sn})$ & 63,68 & 61,40 & 139,24 & 63,85 & 61,04 & 139,02 & 58,52 & 57,56 & 137,41 \\
\hline \multirow{5}{*}{ 号 } & $\mathrm{EI}\left(\mathrm{mm}^{2}\right)$ & 3955,26 & 3965,59 & 3955,25 & 3716,76 & 3725,12 & 3716,73 & 2291,42 & 2298,95 & 2290,19 \\
\hline & $\overline{\mathrm{x}}\left(\mathrm{mm}^{2}\right)$ & 4010,78 & 3971,33 & 3955,34 & 3749,95 & 3729,64 & 3716,73 & 2296,70 & 2304,51 & 2290,19 \\
\hline & $\mathrm{EK}\left(\mathrm{mm}^{2}\right)$ & 4184,49 & 3978,12 & 3955,82 & 3902,78 & 3740,36 & 3716,73 & 2337,66 & 2309,44 & 2309,44 \\
\hline & S & 78,99 & 4,97 & 0,20 & 56,53 & 4,74 & 0,00 & 14,40 & 2,99 & 0,00 \\
\hline & $\mathrm{t}_{\mathrm{w}}(\mathrm{sn})$ & 124,61 & 116,48 & 272,18 & 98,82 & 94,96 & 249,01 & 91,94 & 97,67 & 250,86 \\
\hline \multirow{5}{*}{ ¿̊. } & $\mathrm{EI}\left(\mathrm{mm}^{2}\right)$ & 3955,36 & 3961,83 & 3955,25 & 3717,05 & 3720,53 & 3716,73 & 2291,05 & 2299,11 & 2290,19 \\
\hline & $\overline{\mathrm{x}}\left(\mathrm{mm}^{2}\right)$ & 3971,51 & 3967,09 & 3955,25 & 3743,90 & 3728,15 & 3716,75 & 2292,79 & 2302,36 & 2290,19 \\
\hline & $\mathrm{EK}\left(\mathrm{mm}^{2}\right)$ & 4022,45 & 3976,53 & 3955,25 & 3852,48 & 3736,46 & 3716,81 & 2295,91 & 2308,87 & 2290,20 \\
\hline & S & 25,50 & 5,09 & 0,00 & 44,24 & 4,85 & 0,03 & 1,30 & 3,06 & 0,00 \\
\hline & $\mathrm{t}_{\mathrm{w}}(\mathrm{sn})$ & 153,59 & 184,18 & 486,79 & 182,14 & 187,90 & 481,23 & 178,97 & 181,51 & 479,73 \\
\hline \multirow[t]{2}{*}{$n$} & Durum & \multicolumn{3}{|c|}{ SM-2B } & \multicolumn{3}{|c|}{ SM-3A } & \multicolumn{3}{|c|}{ SM-3B } \\
\hline & & Jaya & SCA & TLBO & Jaya & SCA & TLBO & Jaya & SCA & TLBO \\
\hline \multirow{5}{*}{ 只 } & EI $\left(\mathrm{mm}^{2}\right)$ & 1976,18 & 1981,60 & 1975,99 & 1919,36 & 1924,37 & 1919,34 & 1775,90 & 1782,00 & 1775,88 \\
\hline & $\overline{\mathrm{x}}\left(\mathrm{mm}^{2}\right)$ & 1976,77 & 1987,80 & 1975,99 & 1935,08 & 1931,13 & 1919,34 & 1785,94 & 1786,08 & 1775,88 \\
\hline & $\mathrm{EK}\left(\mathrm{mm}^{2}\right)$ & 1978,04 & 1996,47 & 1975,99 & 1961,93 & 1938,78 & 1919,34 & 1806,49 & 1789,52 & 1775,88 \\
\hline & S & 0,48 & 4,89 & 0,00 & 15,10 & 3,93 & 0,00 & 9,64 & 2,59 & 0,00 \\
\hline & $\mathrm{t}_{\mathrm{w}}(\mathrm{sn})$ & 57,51 & 56,89 & 135,71 & 55,91 & 56,32 & 138,22 & 54,58 & 61,73 & 139,97 \\
\hline \multirow{5}{*}{ 号 } & EI $\left(\mathrm{mm}^{2}\right)$ & 1976,44 & 1984,37 & 1975,99 & 1919,36 & 1926,50 & 1919,34 & 1776,10 & 1780,94 & 1775,88 \\
\hline & $\overline{\mathrm{x}}\left(\mathrm{mm}^{2}\right)$ & 1977,42 & 1987,35 & 1975,99 & 1928,09 & 1929,47 & 1919,34 & 1786,57 & 1783,87 & 1775,88 \\
\hline & $\mathrm{EK}\left(\mathrm{mm}^{2}\right)$ & 1979,62 & 1991,01 & 1975,99 & 1940,01 & 1934,81 & 1919,34 & 1797,34 & 1787,17 & 1775,88 \\
\hline & S & 1,20 & 2,38 & 0,00 & 7,60 & 2,71 & 0,00 & 6,80 & 2,11 & 0,00 \\
\hline & $\mathrm{t}_{\mathrm{w}}(\mathrm{sn})$ & 98,36 & 94,82 & 278,97 & 107,67 & 118,71 & 330,81 & 91,90 & 95,09 & 249,28 \\
\hline \multirow{5}{*}{ 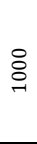 } & $\mathrm{EI}\left(\mathrm{mm}^{2}\right)$ & 1977,21 & 1981,86 & 1975,99 & 1927,64 & 1923,27 & 1919,34 & 1776,03 & 1780,83 & 1775,88 \\
\hline & $\overline{\mathrm{x}}\left(\mathrm{mm}^{2}\right)$ & 1978,37 & 1985,94 & 1975,99 & 1932,35 & 1927,15 & 1919,34 & 1784,98 & 1783,69 & 1775,88 \\
\hline & $\mathrm{EK}\left(\mathrm{mm}^{2}\right)$ & 1982,47 & 1990,98 & 1975,99 & 1941,08 & 1932,00 & 1919,34 & 1793,10 & 1786,69 & 1775,88 \\
\hline & S & 1,60 & 2,90 & 0,00 & 4,51 & 2,70 & 0,00 & 5,85 & 1,85 & 0,00 \\
\hline & $t_{w}(s n)$ & 181,89 & 182,18 & 487,40 & 175,20 & 183,24 & 484,65 & 177,70 & 181,72 & 478,73 \\
\hline
\end{tabular}


Tablo 9'da üç farklı popülasyon büyüklüğü için elde edilmiş karşılaștırma parametreleri verilmiştir. En iyi sonuçlar (EI) değerlendirildiğinde, tüm varyasyonlarda TLBO algoritması ile daha başarılı sonuçlar elde edildiği görülmektedir. Varyasyonların büyük çoğunluğunda Jaya algoritması da TLBO'ya oldukça yakın sonuçlar bulurken SCA en düşük performansı göstermiștir. Ortalama $(\overline{\mathrm{x}})$ ve en kötü (EK) sonuçlar değerlendirildiğinde, TLBO en başarılı sonuçları bulurken bunu genellikle SCA izlemiştir. Jaya algoritması ise bu parametrelerde çoğu varyasyon için en başarısız değerleri elde etmiştir. En iyi değerleri elde etmede oldukça başarılı olan Jaya algoritmasının bu parametreler için en başarısız sonuçları vermesinin sebebinin, çoğu durum için diğer algoritmalardan daha yüksek standart sapmalı sonuçlar elde etmesinden kaynaklandığı düşünülmektedir.

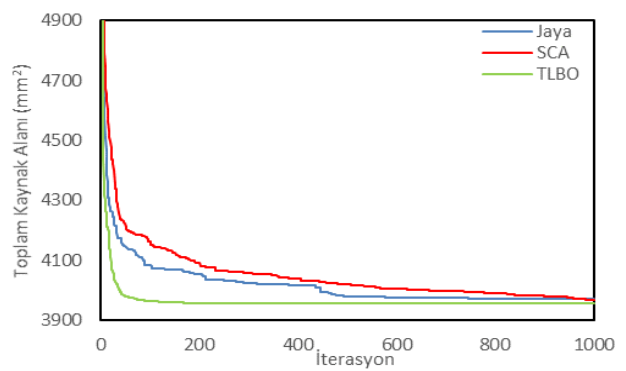

a) $\mathrm{SM}-1 \mathrm{~A}$

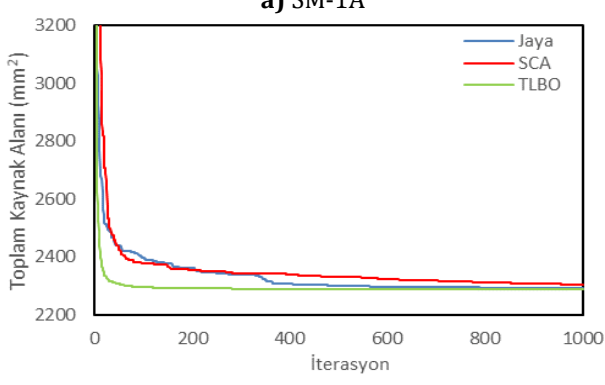

c) $\mathrm{SM}-2 \mathrm{~A}$

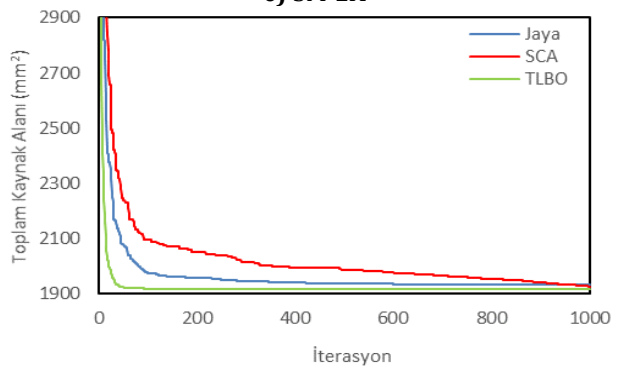

e) $\mathrm{SM}-3 \mathrm{~A}$
Standart sapmalar (S) değerlendirildiğinde, TLBO algoritması sıfıra oldukça yakın standart sapmalar elde ederek en kararlı davranışı göstermiștir. SCA ise genellikle Jaya'dan daha küçük standart sapmalar ile daha kararlı değerler elde etmiştir.

İşlem süreleri $\left(t_{w}\right)$ değerlendirildiğinde, Jaya algoritması ile SCA'nın performansları birbirine yakın bulunmuştur. TLBO algoritması ise eşit çalıştırma koşullarında diğer algoritmaların iki ila üç katı kadar fazla sürede çözüm bulabilmiştir. TLBO özdeş geliştirmenin yapıldığı durumlarda (diğer algoritmalarn yarısı kadar popülasyon elemaniyla) da süre bakımından en başarısız algoritma iken çalıştırma koşullarının TLBO aleyhine olduğu durumlar incelendiğinde sonuç değişmektedir. TLBO algoritması ile $n=250$ eleman ile elde edilen sonuçlar Jaya ve SCA için $n=1000$ eleman

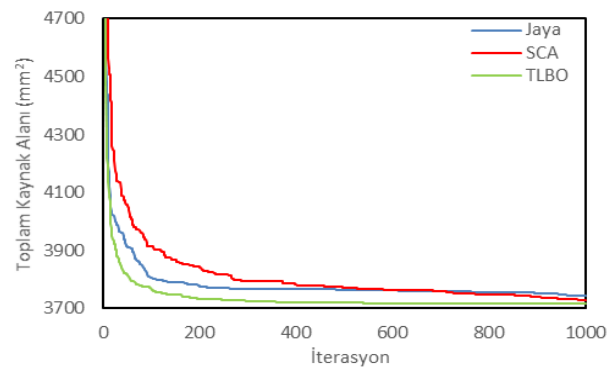

b) $\mathrm{SM}-1 \mathrm{~B}$

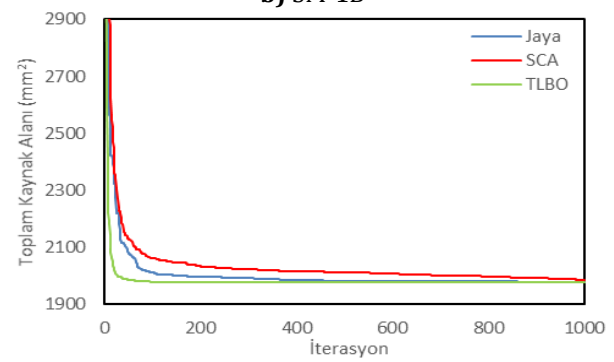

d) $\mathrm{SM}-2 \mathrm{~B}$

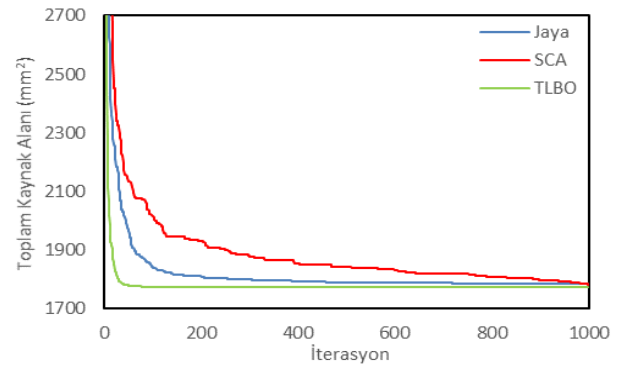

f) $\mathrm{SM}-3 \mathrm{~B}$

Şekil 4. İterasyon-toplam kaynak alanı grafikleri. 
ile elde edilen sonuçlardan hem daha başarılıdır hem de analizleri daha kısa sürelerde tamamlanmıştır.

Şekil 4'te, her biri 1000 iterasyonluk 10 çalıştırma için ortalama değerler ile elde edilen iterasyon - toplam kaynak alanı grafikleri verilmiştir. Grafikler $n=1000$ elaman için yapılan analizler esas alınarak oluşturulmuștur. Grafikler incelendiğinde, TLBO algoritmasının her durumda global optimuma ilk ulaşan algoritma olduğu açıkça görülmektedir. Jaya algoritması ve SCA kıyaslandığında; SM-1A ve SM-1B için iterasyonun erken aşamalarında Jaya algoritması daha başarılıyken, iterasyon ilerledikçe SCA'nın öne geçtiği gözlenmiştir. SM$2 \mathrm{~A}$ ve SM-2B için iki algoritmanın performansı iterasyonun ilk aşamalarında birbirine yakınken sürecin genelinde Jaya algoritmasının daha başarılı ilerlediği görülmüştür. SM-3A ve SM-3B için ise Jaya algoritmasının TLBO'ya yakın bir performans göstererek SCA'dan pozitif ayrıștığ gözlenmiștir.

\section{Tartışma ve Sonuc}

$\mathrm{Bu}$ çalışmada Jaya, TLBO ve Sinüs - Kosinüs algoritmaları ile çelik yapıların kaynaklı birleşimlerinin optimum tasarımlarının yapılması, ilgili metasezgisel algoritmaların sonuçlarının tanımlanan sayısal modeller ekseninde karşılaştırılarak hangi algoritmanın hangi spesifik konuda diğerlerinden daha avantajlı olduğunun belirlenmesi ve bu çalışmada sunulmuş olan Adil Ceza Yöntemi'nin kısıtlı optimizasyon problemlerinin çözümü için kullanılabilirliğinin araştırılması hedeflenmiştir. $\mathrm{Bu}$ hedef doğrultusunda ÇYTHYDE-2018 için tanımlanan gereklilikleri yerine getiren üç adet sayısal model oluşturularak yönetmelikte tanımlanan iki farklı tasarım prensibi ve üç farklı popülasyon büyüklüğü için toplamda 54 adet analiz gerçekleștirilmiștir. $\mathrm{Bu}$ çalıșma neticesinde ulaşlan sonuçlar şu şekildedir:

a. Yapılan 54 farklı analizin sonuçları değerlendirildiğinde; bulunan optimum kaynak alanlarının son derece tutarlı olduğu, ÇYTHYDE2018 yönetmeliğinde belirtilen tüm şartları yerine getirdiği ve her bir sayısal model için maksimum kapasite kullanımını sağlayan minimum kaynak alanlarının elde edildiği görülmüştür. Buradan hareketle Jaya, TLBO ve Sinüs - Kosinüs algoritmalarının çelik yapıların kaynaklı birleşimlerinin optimum tasarımı için kullanılabilir ve hılı çözümler sunan başarılı algoritmalar olduğu anlaşılmaktadır.

b. Analizler algoritma bazında karşılaştırılacak olursa, TLBO algoritması tüm durumlar için Jaya ve Sinüs - Kosinüs algoritmalarından daha başarılı sonuçlara ulaștığı görülmüştür. TLBO algoritması ile diğer algoritmalar karşılaştırılırken TLBO'nun çift fazlı, SCA ve Jaya'nın ise tek fazlı olduğu dikkate alınmalıdır. Çalıștırma parametreleri eşit seçilirse TLBO çift fazlı süreç sayesinde iki kat daha fazla geliştirme yapmaktadır. Daha adil bir karșlaștırma yapılabilmesi için çalıştırma parametreleri eșit değil geliştirme sayısı özdeş olacak şekilde seçilebilir. Aynı geliștirme sayılarının elde edilebilmesi için TLBO'nun diğer algoritmaların yarısı kadar popülasyon elemanı ile yaptığı optimizasyonlar esas alınmalıdır. Eșit geliştirme sayısı ile yapılan karşılaștırmalarda, analiz süreleri hariç tüm parametrelerde TLBO algoritmasının daha başarılı sonuçlara ulaştığı görülmüștür dolayısıyla TLBO için hesaplama maliyetinin daha yüksek olmasından başka bir dezavantaj tespit edilememiştir. Çalıştırma parametreleri TLBO algoritmasının aleyhinde seçildiğinde bile (TLBO için popülasyon eleman sayısı $n=250$, SCA ve Jaya için $n=1000$ ), TLBO'nun diğer algoritmaların yarısı kadar geliştirme sayısı ile daha başarılı sonuçlara ulaştığı, eșit geliştirme sayısıyla yapılan karşılaştırmaların aksine hesaplama maliyetlerinin de daha düșük olduğu görülmüștür. Ayrıca tüm analizler için TLBO algoritmasının sıfıra oldukça yakın standart sapma değerleri elde edebilecek kadar kararlı çalıştığı gözlenmiştir. TLBO algoritmasının çok yüksek kararlılıkta çalışmasında bir iterasyon için iki geliştirme yapan çift fazlı sürecin büyük katkısı olduğu düşünülmektedir.

c. Jaya ve Sinüs - Kosinüs algoritmaları karșılaștırıldığında ortalama performansları birbirine yakın bulunmuștur. Bu iki algoritma ile yapılan analizler birbirlerine yakın sürelerde tamamlanmıştır. Analizlerin büyük çoğunluğunda Jaya algoritması en iyi sonucu bulmakta daha başarılıyken SCA ise daha küçük standart sapmalar vererek daha kararlı sonuçlar bulmuștur. Bu bağlamda, Jaya algoritmasının global optimumu bulmakta, SCA'nın ise her bir çalıștırma için yakın ve kendi içerisinde tutarlı sonuçlar tespit etmekte daha başarılı olduğu söylenebilir. Sonuçlar değerlendiriliyorken SCA'nın parametreli bir algoritma olduğu ve 
farklı parametre ayarlamaları ile daha iyi ya da daha kötü sonuçlar alınabilme ihtimalinin bulunduğu unutulmamalıdır. Bununla beraber, algoritmalar arasındaki karşılaştırmaların bu çalışmada sunulan problemler özelinde yapılmış olduğu ve farklı optimizasyon problemleri için yapılacak karșılaștırmalarda algoritma performanslarının değişkenlik gösterebileceği bilinmelidir.

\section{Kaynakça}

[1] Pham, D. T., Karaboga, D. 2000. Intelligent Optimisation Techniques. Springer-Verlag, London 302s.

[2] Talbi, E. G. 2009. Metaheuristic: from Design to Implementation. 2nd Edition. Wiley, New Jersey, 624s.

[3] Yildiz, A. R., Abderazek, H., Mirjalili, S. 2020. A Comparative Study of Recent NonTraditional Methods for Mechanical Design, Optimization Archives of Computational Methods in Engineering, Cilt. 27, s. 1031-1048. DOI: 10.1007/s11831-01909343-x

[4] Kennedy, J., Eberhart, R. C. 1995. Particle Swarm Optimization. Proceedings of IEEE International Conference on Neural Networks. November 27 December 1, Perth, 1942-1948.

[5] Dorigo, M., Birattari, M., Stutzle, T. 2006. Ant Colony Optimization-Artificial Ants as a Computational Intelligence Technique, IEEE Computational Intelligence Magazine, Cilt. 1, s. 28-39. DOI: 10.1109/CI-M.2006.248054

[6] Karaboğa, D., Baștürk, B. 2007. A Powerful and Efficient Algorithm for Numerical Function Optimization: Artificial Bee Colony (ABC) Algorithm, Journal of Global Optimization, Cilt. 39, s. 459-471. DOI: $10.1007 / \mathrm{s} 10898-007-9149-\mathrm{x}$

[7] Yang, X. S. 2010. Nature-Inspired Metaheuristic Algorithms. 2nd Edition. Luniver Press, Fome, 147s.

[8] Gandomi, A. H., Yang, X. S., Alavi, A. H. 2013. Cuckoo Search Algorithm: A Metaheuristic Approach to Solve Structural Optimization Problems, Engineering with Computers, Cilt. 29, s. 17-35. DOI: $10.1007 /$ s00366 011-0241-y

[9] Holland, J. H. 1975. Adaptation in Natural And Artificial Systems. University of Michigan Press, Ann Arbor, 194s.

[10] Storn, R., Price, K. 1995. Differential Evolution-A Simple and Efficient Adaptive Scheme for Global Optimization Overcontinuous Spaces, Report No: TRICSI 95-012, 15p.

[11] Beyer, H. G., Schwefel, H. P. 2002. Evolution Strategies a Comprehensive Introduction, Natural Computing, Cilt. 1, s. 3-52. DOI: 10.1023/A:1015059928466

[12] Koza, J. R. 1994. Genetic Programming II, Automatic Discovery of Reusable Subprograms. MIT Press, Cambridge, 746s. d. Elde edilen optimizasyon sonuçlarının tamamı algoritma kısıtlarını, dolayısıyla ÇYTHYDE-2018 için tanımlanan sınırlayıcıları sağlamaktadır. İlgili kısıtların sağlanabilmesi için bu çalıșmada sunulan "Adil Ceza Yöntemi" başarılı bulunmuştur. Yöntemin kisıtlı optimizasyon problemlerinin çözümünde cezalandırma işlevi sağlamak üzere kullanılabilir olduğu anlaşılmıştır.

[13] Kirkpatrick, S., Gelatt, C. D., Vecchi, M. P., 1983. Optimization by Simulated Annealing, Science, Cilt. 220,s. 671-680. DOI: 10.1126/science.220.4598.671

[14] Erol, O. K., Eksin, I. 2006. A New Optimization Method: Big Bang- Big Crunch, Advances in Engineering Software, Cilt. 37, s. 106-111. D0I: 10.1016/j.advengsoft.2005.04.005

[15] Hatamlou, A. 2013. Black hole: A New Heuristic Optimization Approach for Data Clustering, Information Sciences, Cilt. 222, s. 175-184. DOI: 10.1016/j.ins.2012.08.023

[16] Kaveh, A., Khayatazad, M. 2012. A New MetaHeuristic Method: Ray Optimization, Computers \& Structures, Cilt. 112, s. 283-294. DOI: 10.1016/j.compstruc.2012.09.003

[17] Schmit, L. A. 1960. Structural Design by Systematic Synthesis. 2nd Conference on Electronic Computation, September 8-9, Pittsburgh, 105-132.

[18] Saka, M. P., Hasançebi, O., Geem, Z. W. 2016. Metaheuristics in Structural Optimization and Discussions on Harmony Search Algorithm, Swarm and Evolutionary Computation, Cilt. 28, s. 88-97. DOI: 10.1016/j.swevo.2016.01.005

[19] Saka, M. P. 1991. Optimum Design of Steel Frames with Stability Constraints, Computers and Structures, Cilt. 41, s. 1365-1377. DOI: 10.1016/0045-7949(91)90274-P

[20] Daloğlu, A., Armutçu, M. 1998. Genetik Algoritma ile Düzlem Çelik Çerçevelerin Optimum Tasarımı, Teknik Dergi, Cilt. 116, s. 1601-1615.

[21] Daloğlu, A., Aydın, Z. 1999. Kafes Sistemlerin Uygulamaya Yönelik Optimum Tasarımı, Pamukkale Üniversitesi Mühendislik Fakültesi Mühendislik Bilimleri Dergisi, Cilt. 5, s. 951-957.

[22] Kameshki, E. S., Saka, M. P. 2001. Optimum Design of Nonlinear Steel Frames with Semi-Rigid Connections Using a Genetic Algorithm, Computers and Structures, Cilt. 79, s. 1593-1604. DOI: 10.1016/S0045-7949(01)00035-9

[23] Hayalioğlu, M. S., Değertekin, S. Ö. 2005. Minimum Cost Design of Steel Frames with Semi-Rigid Connections and Column Bases via Genetic Optimization, Computers and Structures, Cilt. 83, s. 1849-1863. DOI: 10.1016/j.compstruc.2005.02.009

[24] Kaveh, A., Talatahari, S. 2007. A Discrete Particle Swarm Ant Colony Optimization for Design of Steel Frames, Asian Journal of Civil Engineering Building and Housing, Cilt. 9, s. 563-575. 


\section{DEÜ FMD 24(70), 277-290, 2022}

[25] Saka, M. P. 2009. Optimum Design of Steel Sway Frames to BS5950 Using Harmony Search Algorithm, Journal of Constructional Steel Research, Cilt. 65, s. 36-43. DOI: 10.1016/j.jcsr.2008.02.005

[26] Toğan, V. 2012. Design of Planar Steel Frames Using Teaching-Learning Based Optimization, Engineering Structures, Cilt. $34, \quad$ s. 225-232. DOI: 10.1016/j.engstruct.2011.08.035

[27] Ragsdell, K. M., Phillips, D. T. 1976. Optimal Design of a Class of Welded Structures Using Geometric Programming, ASME Journal of Manufacturing Science and Engineering, Cilt. 98, s. 1021-1025. DOI: $10.1115 / 1.3438995$

[28] Coello, C. A. C. 2000. Use of a Self-Adaptive Penalty Approach for Engineering Optimization Problems, Computers in Industry, Cilt. 41, s. 113-127. D0I: 10.1016/S0166-3615(99)00046-9

[29] Lee, K. S., Geem, Z. W. 2005. A New Meta-Heuristic Algorithm for Continuous Engineering Optimization: Harmony Search Theory and Practice, Computer Methods in Applied Mechanics and Engineering, Cilt 194, s. 3902-3933. DOI: 10.1016/j.cma.2004.09.007

[30] Kaveh, A., Talatahari, S. 2010. A novel heuristic optimization method: charged system search, Acta Mechanica, Cilt. 213, s. 267289. DOI:10.1007/s00707-009-0270-4

[31] Mirjalili, S., Mirjalili, S. M., Lewis, A. 2014. Grey Wolf Optimizer, Advances in Engineering Software, Cilt. 69, s. 46-61. DOI:10.1016/j.advengsoft.2013.12.007

[32] David, D. C. N., Stephen, S. E. A., Ajoy, J. A. 2016. Cost Minimization of Welded Beam Design Problem Using PSO, SA, PS, GOLDLIKE, CUCKOO, FF, FP, ALO, GSA and MVO, International Journal of Applied Mathematics, Cilt. 5, s. 1-14.
[33] Alberdi, R., Murren, P., Khandelwal, K. 2015. Connection Topology Optimization of Steel Moment Frames Using Metaheuristic Algorithms, Engineering Structures, Cilt. 100, s. 276-292. DOI: 10.1016/j.engstruct.2015.06.014

[34] Jin, S., Ohmori, H., Lee, S. 2017. Optimal Design of Steel Structures Considering Welding Cost and Constructability of Beam-Column Connections, Journal of Constructional Steel Research, Cilt. 135, s. 292-301. DOI: 10.1016/j.jcsr.2017.03.020

[35] Celik Yapıların Tasarım, Hesap ve Yapımına Dair Esaslar. 2018. Resmî Gazete, 15 Șubat 2018, Sayı 30333.

[36] Sezer, S. 2021. Celik Yapıların Kaynaklı Birleşimlerinin Metasezgisel Yöntemlerle Optimum Tasarımı, Afyon Kocatepe Üniversitesi, Fen Bilimleri Enstitüsü, Yüksek Lisans Tezi, 110s, Afyonkarahisar.

[37] Rao, R. V. 2016. Jaya: A Simple and New Optimization Algorithm for Solving Constrained and Unconstrained Optimization Problems, International Journal of Industrial Engineering Computations, Cilt. 7, s. 19-34. DOI: 10.5267/j.ijiec.2015.8.004

[38] Rao, R. V., Savasani, V. J., Vakharia, D. P. 2011. Teaching-Learning-Based Optimization: A Novel Method for Constrained Mechanical Design Optimization Problems, Computer-Aided Design, Cilt.. 43, s. 303-315. DOI: 10.1016/j.cad.2010.12.015

[39] Mirjalili, S. 2015. SCA: A Sine Cosine Algorithm for Solving Optimization Problems, Knowledge-Based Systems, Cilt. 96, s. 120-133. DOI: 10.1016/j.knosys.2015.12.022

[40] MATLAB. 2016. version 9.0.0 (R2016a), The MathWorks Inc., Natick, Massachusetts. 